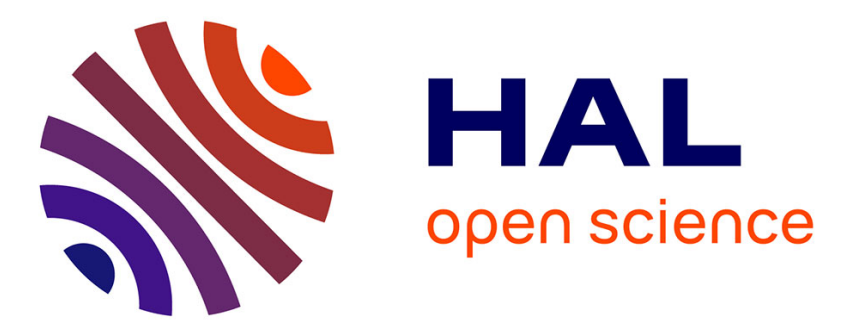

\title{
Rethinking Theory and Practice of ICT4D. An Analysis of the Discourse Embedded in the 2016 World Bank Report
}

\author{
Calisto Kondowe, Wallace Chigona
}

\section{To cite this version:}

Calisto Kondowe, Wallace Chigona. Rethinking Theory and Practice of ICT4D. An Analysis of the Discourse Embedded in the 2016 World Bank Report. 15th International Conference on Social Implications of Computers in Developing Countries (ICT4D), May 2019, Dar es Salaam, Tanzania. pp.135-148, 10.1007/978-3-030-19115-3_12 . hal-02281303

\section{HAL Id: hal-02281303 \\ https://hal.inria.fr/hal-02281303}

Submitted on 9 Sep 2019

HAL is a multi-disciplinary open access archive for the deposit and dissemination of scientific research documents, whether they are published or not. The documents may come from teaching and research institutions in France or abroad, or from public or private research centers.
L'archive ouverte pluridisciplinaire HAL, est destinée au dépôt et à la diffusion de documents scientifiques de niveau recherche, publiés ou non, émanant des établissements d'enseignement et de recherche français ou étrangers, des laboratoires publics ou privés. 


\title{
Rethinking Theory and practice of ICT4D. An analysis of the discourse embedded in the 2016 World Bank report.
}

\author{
Calisto Kondowe ${ }^{1}$ [0000-0002-0845-3157] and Wallace Chigona ${ }^{2}$ [0000-0002-1059-811X] \\ ${ }^{1}$ University of Cape Town, Cape Town, South Africa \\ ${ }^{2}$ University of Cape Town, Cape Town, South Africa \\ kcalistos@gmail.com
}

\begin{abstract}
Although development studies/theory is critical in all areas pertaining to global development, Information and Communication Technology for development (ICT4D) studies have been argued to have paid little attention to the controversies around development. I argue that all ICT4D research uncover the meaning of development but this is often implicit; and this meaning can be revealed using techniques such as discourse analysis (CDA). The study is a CDA of World Bank Report 2016 on Digital Dividends (WDR16) to illustrative how CDA can be applied to expose implicit views of development embedded in ICT4D studies. The study is centred on the recent growing emphasis on ICTs for development focusing on contemporary processes of social transformation which are variously identified within the critical discourse analysis (CDA) by such terms as 'neo-liberalism', 'globalisation', 'information society' and 'knowledge-based economy'. Although the report can be critiqued for over-emphasis of positive contributions of ICT4D, it needs to be applauded for taking development not as merely market related but as a holistic process covering other socioeconomic development issues like poverty eradication, human development and human dignity. It resembled major shifts in ICT4D thinking from 2000 to 2010 which was a move from technocentric view.
\end{abstract}

Keywords: World Bank, ICT4D, economic growth, digital dividends, globalisation, development studies

\section{Introduction}

The rising poverty and inequality within and among nations and many other global developmental challenges have left many critical questions as to whether diffusion of ICTs can lead to development or whether they reinforce the divide and uneven development. This central argument is critical as the main debate in development policy and practice has been always on the disparities between and 
within nations. The assumption that ICTs adoption and use can contribute to reducing the massive inequity that exists between and within nations is questioned, as the gap is widening (Kondowe, 2018). Furthermore, the observations that the poor will benefit from the development of ICTs was critiqued as too simplistic and abstract, vague, complex (Bongo, 2005; Kondowe, 2018). The question of ICT-enabled development remains a heated debate in ICT4D studies and the central critique has been that they do not tap into the central discussions on the theory and practice of development studies. Though several studies have claimed that ICTs have a number of contributions to development whether implied or explicit, to date literature that integrates ICT4D debates into the mainstream development ideas is argued to be sparse. The central question as to what ICTs mean within the language of development studies is argued to be unanswered and in ferment.

It is critical from the onset to acknowledge a number of ICT4D studies that have explicitly argued about the contribution of ICTs in development through poverty eradication, economic growth, better health and education (Bankole et al. 2015; May et al. 2014; Miroro and Adera 2014; Levendis and Lee 2013). The field also recently witnessed the use of many derivative frameworks: for example, the capability approach, millennium development goals for example by Clarke, Wylie and Zomer (2013) and Kleine's Choice Framework. Nonetheless a majority of the ICT4D sources are implicit about technology enabled development. Research and studies in ICT4D have been critiqued as flawed due to the lack of a unified conceptual grounding in development studies. Studies were described as complex, ambiguous, and often laden with conflicting and antagonistic views lacking clarity on how ICT is conceptualised in the context of development (Avgerou, 2010; Kondowe, 2018). Moreover, studies fail to come up with convincing arguments regarding technology-enabled development and how it can be achieved (Avgerou, 2010). Furthermore, development debates occupy a lesser space in ICT4D debates (Wade, 2002). In some contexts where there is an attempt to conceptualise, there is a lack of reference to important aspects surrounding development that can provide a more comprehensive explanation (Harindranath and Sein 2007). It is thus clear that scholars have expressed discontent regarding the progress within the technology-enabled development debates.

Although development studies/theory is critical in all areas pertaining to global development, ICT4D studies have been argued to paying less attention to the controversies around development (Avgerou, 2010), hence lacking a solid understanding of development outcome (2001). In support of this, Heeks (2006:1) argued that "we are changing the world without interpreting or understanding it". The process by which ICTs foster socio-economic development is argued to be unclear (Thapa and Sein 2010). Thus, although there is a growing literature on ICTs in developing countries (Walsham and Sahay 2006; Avgerou, 2008), a number of researchers, for example, have argued that much of this literature does not address the question of what is meant by development (Heeks, 2006; Thompson, 2008). In an article in the policy arena recently published in the Journal of International Development, Richard Heeks argues that the development informatics community has been informed 
much more by academics with a technical bias (for example, those from the information sciences, information systems, communication studies, and computer science disciplines) than those with a development studies focus (Heeks, 2010). It is clear that ICT4D as a discipline is found wanting in terms of conceptualising development.

Although studies have been critiqued for lacking a unified conceptual understanding of what development is, several studies have managed to imply what they mean by development. It is evident that many studies in ICT4D have done a great deal in pointing to the weaknesses; amidst this dark picture, "development" as a concept in ICT4D studies has been emerging as a cross-cutting theme. Scholars and researchers need to be applauded for thinking/rethinking and conceptualising/reconceptualising development. It may be an under-specification, if the contributions to framing of development are overlooked. Amidst these critiques, however, a number of studies articulate the link between ICT, economic growth and poverty eradication (May et al. 2014; Miroro and Adera 2014). There has been progress in identifying a myriad of ways in which ICTs contribute to development. ICTs are argued to have made the world more inclusive (World Bank, 2016). ICTs are also positioned such that they have transformative potential in all spheres of the economy. ICTs in general are portrayed as a catalyst, a tool that can enable development and has many positive contributions to development (World Bank, 2002; Acilar, 2011). There is a bold stance that the question of whether ICTs can contribute to development has come to have an obvious "Yes" answer (Walsham, Robey and Sahay 2007). In this study, I argue from the outset that the fact that these studies make reference to development studies, does not in itself make reference to what they see development as. Although they may not be explicit in stating the nature and kind of development that ICTs pursue or contribute to, it is clear that they imply a set of principles which mirror orthodox and neo-liberal development.

\section{Understanding Development Studies/Theory}

Concern over development has been at the core of theory and practice for decades. Development studies is complex; there is no agreed way of analysing development. Scholars and practitioners thus face critical choices regarding focus, scale and expertise (Currie-Alder, 2016). Conceptualisations of development have been diverse. Development studies is multidisciplinary and has, for several decades, been connecting different thinkers in different fields, such as economics, sociology and history, amongst others. Early conceptualisations have been based on development as purely economic growth within the neo-liberal school until recently when the field witnessed the nature of explanation shifting from merely economic growth to other aspects in socio-economic development and human development.

The field has been preoccupied with analysing the existence of poverty and inequalities in societies (Pieterse, 2010). Recently, development studies is engaging with several issues around environment 
management, peace, and climate change, amongst other critical concerns. Moreover, it is seen as the improvement of human wellbeing, the human condition or welfare. Although there have been shifts in development studies from economic growth to human development as new developments and new frameworks forged consensus by prioritising reducing extreme poverty, they remained compatible with neo-liberal growth economics (Clarke et al. 2013). Development studies is thus embedded within orthodox and neo-liberal thinking. This study will discuss the orthodox approach which is mainly in the neo-liberal school.

\section{Orthodox Approach to Development}

The orthodox approach refers to the early conceptualisation of development which was primarily preoccupied with economic growth (Ranis, 2004). This was the thinking that emerged after World War II, as independent countries sought advice for the acceleration of their development (Rapley, 2007). At that time, the Western world was confronted with the challenge of rebuilding countries that had been destroyed by war. Simultaneously, there was also a concern regarding the challenges alongside facing backward regions and countries, and the solution that was devised was that these challenges could only be overcome by the pursuit of economic growth through industrialisation. Capital accumulation was at the heart of development and was seen as the necessary requirement for development. The approach emphasised the importance of markets. The states were supposed to create an enabling environment which was market-friendly. The resulting growth theories assumed that wealth generated through economic growth would trickle down and eventually benefit all segments of society. This therefore primarily focused on the requirements for an increase in per capita real income. Development was considered largely synonymous with industrialisation and economic growth. Technologies, new ingestions and innovations were idealised as a momentum to bring economic improvements to the less-developed and developing regions (Hwang, 2006). The ultimate goal was to raise incomes and, in the process, give the poor people access to the range of goods and services. Industrialisation was seen as the path to raise incomes, and the benefits of economic growth were envisaged as if they would trickle down to the poor. However, development thinking should be applauded, with significant scholars propounding conceptualisations incorporating human development following Sen's (1999) ground-breaking capability approach to development that focused on empowerment, amongst other approaches. Moreover, millennium development goals and human development reports, which were adopted by the United Nations to track practice, were associated with human development. As positive as steps such as these appeared on the surface, these developments, according to Clarke et al. (2013), prioritised reducing extreme poverty; however, to date, development conceptualisation remains compatible with neo-liberal growth economics.

\section{Technology and the New Capitalism Language}


The Frankfurt School, arriving in the mid-20th century, was built on the work of Marx, Weber and Parsons around the interactions of technology and society. Within this school, technology was part of a critique of modernity and the developments and institutions associated with modern society (Richardson et al. 2006). Critical theory allied technology with modernity and viewed it as a tool of the modern state used for more perfect subjugation of both the masses and the individual (Richardson et al. 2006). The study is a critique of the neo-liberal explanations rendered for ICT-enabled development. Although critical research in information systems dates back to the early 1980s (Mingers, 1980; Ngwenyama and Lee 1997), the discipline has been flooded with studies within the positivist paradigm with fewer of a critical nature (Richardson et al. 2006). The role of technology in society emerged from critical philosophers Marx, Weber \& Parsons, who argued that technology has effects in society (Shields, 1997). Technologies have been seen by the Marxists as a replacement of the traditional organisation of the "family-owned and -operated firm with that of the large-scale, centralized, hierarchical, bureaucratic corporation” (Kurz, 1994: 245). The logic behind technology was with a view to maximising economic growth as measured by market share and profitability (Kurz, 1994). Although the explanations that technologies contribute to economic growth may seem substantial, the Marxists, thorough analysis of the function of technologies in the sphere of production, bring clearly into focus an underlying logic guiding the process of mechanical integration and organisation, a logic that the technology optimists failed to see. No doubt stemming from the Marxist thinkers, the integration of technologies into the sphere of production is associated with the economic growth logic of profits and capital accumulation.

Many research studies within the ICT4D discipline may not state the development discourse that they are assuming as guiding them and structuring the information sources and methodologies that they employ in justifying ICTs in enabling development; however, they share a language, vocabulary, common basis and generally agreed principles. This study draws attention to the fact that ICT4D discourses are built, maintained and rearranged in the context within in which any study is taken. The way in which ICT is positioned in development raises questions whether ICT is a panacea of development or economic growth. In this case ICT4D studies shapes development discourses as well. The methodological foundation of the research is based on critical discourse analysis, which draws particular attention to discreet language and the way narratives are formed and interpreted. The methodological framework applied specifically emphasises the role of language and identities in the formation and reproduction of discourses through the hegemonic institutions which are key stakeholders in ICT4D, such as the World Bank. I argue that the way that these hegemonic institutions view technology in development has been the underlying theme that has been transferred to ICT4D studies. Although there has been a major shift from market related and technocentric resemblance of ICT4D the language of orthodox approach to development witnessed minor changes, hence the results reaped within ICT initiatives targeting development have exhibited mixed results. The data analysis 
will investigate the argumentation and legitimisation strategies behind the discourses of ICT and development through these institutors.

\section{Methodology}

The study utilised the critical discourse analysis (CDA) methodology in its investigation of how the World Bank frames ICT-enabled development. CDA is not only a theoretical framework that explores the relationship between language use as discourse and unequal power relations, but also is an analytical method that analyses diverse linguistic features and discursive strategies by which a certain ideological bias is exercised in texts (Hwang, 2006). The discourse analysis as a research tool can be used in exploration and analysis of various policy documents (Byungura et al. 2016). Accordingly, CDA was used in this study as a research approach that is methodologically based on the analysis of the WDR16 is supporting the rhetoric that ICTs are a catalyst that contributes positively to development. The intention to use a CDA approach for this study was to create a deeper knowledge about how development is conceptualised in ICTs and to unpack the implied and articulated concepts that are used in framing development in ICT4D.

I focus my discussion around the arguments in the report which refer to contemporary processes which are ICT-driven and are variously identified within the CDA by such terms as 'neo-liberalism', 'globalisation', 'information society' and 'knowledge-based economy'. These terms and inferences in the ICT4D space have an extremely huge bearing on how development is understood and conceptualised. A focus on these led to greater use, application and reference to the language of new capitalism, the language of globalisation of Fairclough (2003). These terms were used as the central focus to analyse texts that were extracted to discuss the implied meaning of development within the report.

The WDR16 is the data source for the study. The basis of the analysis is a description of new capitalism, written by Jessop (2000), which Fairclough (2003) constantly refers to. The capitalist mode of production has evolved in several ways to include issues such as re-articulation and rescaling the relations between the economic, political, and social (Jessop, 2000). The new capitalism encompasses new technologies and new modes of economic coordination (Fairclough, 2003). The main terms which have entered this language are, for example: the information economy, the knowledge-driven economy, globalisation, the rise of regional economies, entrepreneurial cities, the network economy, strategic alliances, government without governance, turbo capitalism, space-time compression, flexibility, workfare, the learning economy, and the enterprise culture (Fairclough, 2003). The above refer to capital accumulation as the main logic which has dominated the current 
economic state of affairs. ICTs and digital technologies are drivers of this new capitalism and occupy a dominant space in this economic era. It is from this background that this chapter focuses on the discourse of ICTs, economic growth and globalisation, which is portrayed by the WDR16.

The rationale behind selecting the WDR16 on digital dividends was purposive. I basically believe that policy reports are the most valuable resource to recognise the positions and arguments of certain stakeholders. I also see ICT4D as a power struggle for domination and the World Bank as the hegemony of ICT4D, having much control of the direction which it will take. Further, policy reports, in particular those produced by international organisations, are the most important discursive resource to investigate the way in which the discourse of development is being constructed, disseminated, and argued. The World Bank has had the predominant role in global development issues and now has taken a leading role in ICTs. The World Bank is seen as the custodian of development and shapes the direction of development. It is also seen as an institution with technical capacity and competency to deal with development. Although history has condemned some of the policy options that have failed the global South, to date the World Bank is the key institution sometimes referred to the hegemony of development as it provides policy options to development practitioners and shapes the terrain and landscape of global development. I thus analyse texts within the report to elicit what they mirror in development theory. The study utilised only the Part 1 of the report which contains three documents that summarise ICTs and economic growth, expanding opportunities, and promoting service delivery, respectively. I read the full report and purposively focused on Part 1 of the report as it forms the summary of the report. The texts which were analysed were purposively selected as they formed the summary or main argument of the section concerned. This study is part of the major $\mathrm{PhD}$ work in progress which analyses the full report and a wide variety of literature sources.

\section{Findings}

The Positive Contributions of ICTs in Development. The main title, Digital Dividends, introduces the main claim and the underlying assumption in the report which is that ICTs can provide digital opportunities or that they have positive impacts on the global development story. The title is rhetoric: "digital dividends" intends to justify and motivate a shift that would entail presenting ICTs as positive contributors to development. Rhetoric statements set precedence on how the social reality should be viewed, experienced and interpreted (Fairclough, 2003; Guo, 2013). It thus sets the underlying tone of positive contribution of ICTs in development, while choosing paying less attention to negative impacts of ICTs, which is digital divide. Unlike most literature and research in ICT4D, the report partially acknowledge the longstanding debate of the complex relationship between ICT and development from the outset. The report claims that the digital revolution is necessary and contributes to better business operational efficiency and productivity, amongst other benefits. ICTs are presented as drivers and catalysts to unlock digital opportunities and improve the lives of the poor. ICTs also transform the ways in which corporates operate, stimulating productivity, innovation and efficient 
ways of operating which, in turn, lead to profitability, which is the much-desired force to improve GNP and GDP. The report states that ICTs have positive contributions to economic growth and job creation.

\section{$<$ Extract $1>$}

We must take advantage of this rapid technological change to make the world more prosperous and inclusive. This Report finds that traditional development challenges are preventing the digital revolution from fulfilling its transformative potential. For many people, today's increase in access to digital technologies brings more choice and greater convenience. (Foreword) [My emphasis].

The wording of the statement starting "We must take advantage of this rapid technological change..." is suggestive in nature. It glorifies ICTs and makes them a non-negotiable for organisations and countries to tap into it if development is to happen. This statement is accomplished by the metaphor "digital revolution”. Metaphors are used in a number of ways to create social realities and may thus be a guide for future action, which reinforces the power of the metaphor to make experience coherent (Guo, 2013), thus underscoring a specific understanding of the reality while ignoring others. ICTs, in this narrative, are positioned as prerequisites for development, and should be taken advantage of. Although ICTs are important in the development story, there are other contributing factors which are also important, however ICTs remain catalysts and enablers of development.

Key Contents of the Report. As stated earlier, the report has three key policy contents. I discuss the narrative of the three key contents in the report which are the contributions of ICTs in: economic growth, expanding opportunities and promoting service delivery. The theme for ICTs and promoting economic growth inclusion and participation continues to solidify the legitimation of ICTs as a panacea for development. In this paradigm, these digital technologies are accelerating growth and helping businesses become more productive; ICTs expand economic opportunities for individuals, for example, people find jobs and greater opportunities; and lastly ICTs can contribute to better service delivery where governments deliver better public services to all. The report thus shifted from traditional view on markets and techno-hype approach to development as economic growth is seen as a means and not an end of development. Better service delivery and quality of life is seen as an end of development.

Accelerating Growth. The report then reiterates the ways in which ICTs need to be discussed within the global development discourse. It is therefore significant to analyse the discursive formation by which economic growth is conceptualised and constructed within ICTs discourses. Discourses word or lexicalize the world in particular ways (Fairclough, 2003). Due to the more abstract ways in which discourses construct meaning it was imperative to focus on semantic relationships between words and 
not only on individual words that were used in the policy report. According to the report, the three broad ways that ICTs can promote growth is through enabling inclusion, efficiency, and innovation of firms (World Bank, 2016). These three ways are important in expanding trade, increasing capital and labour utilisation, and intensifying competition and are argued to have direct positive impacts on growth. Better communication between firms is argued to contribute to better access to market information. This considers the continued and ever persisting debate of whether development is about economic growth or human development. Although from the surface the report legitimises an orthodox development where economic growth is primary, implicitly it covers deep critical development questions on inclusion.

\section{$<$ Extract 2>}

Digital technologies have dramatically expanded the information base, lowered information costs, and created information goods. This has facilitated searching, matching, and sharing of information and contributed to greater organization and collaboration among economic agents =influencing how firms operate, people seek opportunities, and citizens interact with their governments. The changes are not limited to economic transactions - they also influence the participation of women in the labor force, the ease of communication for people with disabilities, and the way people spend their leisure. [My emphasis].

Texts set up dialogical or polemical relations between their 'own' discourses and the discourses of others (Fairclough, 2003). Beyond supporting the technology, in this extract, optimists emphasise the role of markets/private sector in the development and importance of globalisation. The private sector is thus seen as the key vehicle to bring about development that is needed. If the firms can deliver on productivity, it is expected that these will result in improved GDP which, in turn, would benefit the masses. Development is thus mainly framed within the orthodox school. The rhetoric used in $<$ Extract $2>$ ("information goods") justifies and motivates a shift that would entail the information economy, which speaks to the importance of information in current economic relations and for countries and firms to be competitive in the global market. This rhetoric also furthers the understanding of the information or digital economy, which optimists argue are catalysts for development. Although optimists argue that ICTs are important for development, on the other hand, the pessimists argue that ICTs have reinforced inequality and poverty. The rhetoric is used to reinforce the former view. In as much as the report emphasises the role of ICTs in development it needs to be applauded for taking development not as merely market related but took a holistic approach which encompasses other socio-economic development issues like poverty eradication signalling the shifts in ICT4D thinking from 2000 to 2010 which was a move from technocentric view. 
Expanding Opportunities. Digital technologies are vested with the potential to improve overall welfare and reduce poverty; but without complementary investments, they can also worsen inequality. They are vehicles to enable employment of youth and other vulnerable groups, and assist innovation for farmers and fishermen, among other businesses which are mostly dominated by the poor. Connectivity is also seen as leading to inclusion of women and other marginalised groups into the mainstream economy.

\section{$<$ Extract 3 $>$}

Digital technologies can improve overall welfare and reduce poverty, but without complementary investments, they can also worsen inequality. In Africa alone, 11 million youth are expected to enter the labor market every year for the next decade. Born in the internet era, they live in a world full of new and exciting opportunities. Farmers use mobile phones to get price information and technical advice. Women facing barriers to work outside their homes can work online and better balance work and family. [My emphasis].

The use of ICTs is seen as having far-reaching positive contributions that go beyond the economic benefits discussed in the earlier section. ICTs are major contributors to poverty eradication. They have benefits that spill over to the general populace, for example, women's inclusion in the labour market. The report uses "depoliticisation and the common interest" (Ziai, 2015:13) strategy in order to position ICTs in development. The discourse employed by most development agencies assumes that 'development' is something that benefits everyone and therefore no one can object to it (Ziai, 2015). The intention is that the poor will also benefit from this nature of development. The report assumes that, in a networked society, the poor will also benefit and that there will be opportunities that will be unlocked, and that technology has the power for socio-economic inclusion of the poor. Although the above is important as ICTs are catalytic in unlocking opportunities for the poor, however questions on the extent to which they benefit remain under ferment.

It is important to note that there is great controversy around opportunities that are created by ICTs. While, in the developed countries, technology has opened opportunities, the case is not the same with developing countries, as there are several challenges that are faced. Connectivity challenges due to data costs and skills continue to exclude a large number of the population from participating in the information society. Moreover, although this is widely contested, there is, however, an acknowledgement amongst several scholars that ICTs have brought with them the main challenge of cyber apartheid. There is evidence that ICTs have achieved positive results for developing countries, but the information economy has been critiqued by pessimists in that they reinforced exclusion of developing countries (Heeks, 2008). Moreover, the extract negates analysis of the structural causes of poverty. Technology, at times, may exclude women due to culture; also, costs can exclude the poor 
while skills exclude the illiterate. The inclusive nature of technology portrayed in this statement can thus be questioned.

Delivering Services. ICTs are discussed in the report as important in enabling government's capability to empower citizens through accessing government information, and enhancing democracy and citizen participation, which, in turn, promote transparency and accountability. They are thus empowering tools for citizens. This is important as development is seen as transforming human wellbeing and for people to have voice.

\section{$<$ Extract 4>}

Governments have invested heavily in digital technology over the past two decades, and these efforts have made it easier in many countries for businesses to file taxes, and for the poor to get an official identity allowing them to receive welfare payments and vote in elections. Digital technologies have also enabled governments to receive regular feedback from service users, improving service quality.

In discussing the importance of ICTs in delivering services, the report once again uses "depoliticisation and the common interest" which was used in the previous discussion. Technology is seen as contributed to improving the life of all citizens, including the government itself. It has become easy for governments to deliver and for the citizens to hold the governments accountable. This is a positive step and move from the market related and technocentric approach to development. It is important to note that this is a critical contribution of the report as it signalled a shift to realisation of development as about people. ICTs thus enable participation and for people to live the life they want which resembled major shifts in ICT4D thinking. One of the main propositions of neo-liberal development is the redistributive role of states when markets fail. ICTs have enabled accountability and open government, which is important for human wellbeing, On the contrary however, rural and remote areas have rather excluded the poor from participating due to affordability and access, although this is changing rapidly. Moreover, while the number of democracies is growing, the share of free and fair elections is falling (World Bank, 2016). This indicates that the role of ICTs in holding governments accountable should not be over emphasised.

\section{Discussion}

Whether ICTs promote development or perpetuate poverty, marginalisation and inequality is the major question that has caused ICT4D study to be in ferment. Although the WDR16 legitimates the discourse of ICTs and economic growth and neo-liberal development, the report needs to be applauded for moving from the mere technocratic and market related view of development which was the traditional thinking within ICT4D. It has uncovered issues of socio-economic development and 
has positioned humans as the end of development. It is important to agree that ICTs promote economic growth, provide opportunities, and increase democracy in developing countries (Acilar, 2011). Although the report underspecifies the fact that the poor are often unable to participate in the information society and the digital and global divide is widening. Moreover, poverty and inequality gaps between and within nations is increasing. The poor lack access due to cost, skills and other social factors that impact them. It is thus on this background, the report made clear that ICTs alone do not contribute to development unless necessary inputs are availed.

The three key policy contents and the theme in this report have not been haphazardly selected but have conveniently underspecified the challenges associated with ICTs in development and have supported the technology optimist's perspectives of technology as catalysts and enablers of development. It is clear from the narrative that challenges associated with ICTs are underspecified, while the report is clear on the benefits. Non-hegemonic discourses which are held by technology pessimists are marginalised, displaced and/or excluded within/from the report. Every hegemonic discourse is therefore political in the sense that it admits only one contingent fixation of meaning, excluding other possible meanings. It is thus clear that the report's exclusion of going into further detail around the digital divide and cyber apartheid may be intentional, reinforcing the dominant rhetoric that digital opportunities assume in the theory and practice of ICT4D.

It is within the optimist's perspective that the report, by implication, argued with the neo-liberal theme as the underlying tone of the understanding of ICTs and development (e.g., terms such as knowledge-based society, competitiveness, productivity, efficiency, markets, globalisation and trade); all these have economic growth implication and speak to the theme that development is about economic growth. Although, in a few instances, inclusion of women and the other marginalised groups is mentioned, however, the report implies that they are included in the labour market and employment opportunities are unlocked for them by technology. This shows that the language of economic growth as the goal of development is the underlying thread in this report. They create a hegemony of orthodox approach in development and maintain the underdevelopment and uneven development discourse offered by the orthodox approach. On the contrary however human development remained as central aspect of development as poverty eradication, participation and service delivery were mentioned which are central to development debates.

It is clear that there is overemphasis on the role of markets or the private sector to stimulate development within the ICT4D landscape. The firm or private sector growth is widely acknowledged to be a central institution to lead to employment creation, innovation, and profits which will lead to GDP and GNP growth, which, in turn, is a means for alleviation of poverty through the assumed trickle-down economics. The supreme role of markets in development has been the central theme of orthodox development thinkers. The private sector is also seen as a means of providing more and 
various economic opportunities in different societies. Although the analysis may be true, however, to focus on growth alone generates a risk of creating or exacerbating inequality. In many contexts the private sector is influenced by profits rather than development. The trickle-down economics can thus be questionable.

Globalisation, trade and the formation of world markets is also one key concept that is argued to be facilitated by ICTs. The main goal of globalisation is providing organisations a superior competitive position with lower operating costs, to gain greater numbers of products, services and consumers as well as access to the world market (Veseth, 1998). It is a force for liberal economics where the main aim is the formation of one world market which is not restricted by state boundaries to enhance full participation of market forces. The report argued that globalisation is thus facilitated by the use of ICTs as tools which enhance dynamic trade, exchanges and communication through the production of networks and platforms. Although globalisation is seen in the economic growth perspective as a positive move, there are often uneven and unjust outcomes of globalisation which the report underspecified. Globalisation positions markets as the centre of development, which is the language of orthodox thinkers, moreover, profits and capital accumulation are made to be the logic of development. Although this positions ICTs, as articulated by the report, as falling within the orthodox school of development, the fact that these processes are intended for benefiting and improving the quality of life for individuals is important as it takes into consideration the new frameworks in ICT4D like the capability approach and empowerment approach.

\section{Conclusion}

The way in which the report articulates the relationship between ICT and development depended a great deal on how development itself was understood: what it is and how it can be achieved. It may be that, on the surface, the report is silent about the development ideology it aligns with, but there are a number of inferences and implied assumptions as to the nature of development that they refer to. Development theory/studies is/are central to ICT4D narratives and research. Implied as it can be, the assumptions, values and logic around how development is conceived has been the overarching theme within this report and many other ICT4D studies. This supports that ICT4D debates are inseparable from the fundamental development ideas (Castells, 1999). It is evident from the report that development as concept has been an emergent discourse in ICT4D studies and has been debated in theory and practice, albeit to a greater extent by implication. This is confirmation of its use and, in fact, it is a reflection of the understanding of what development is perceived to be.

This study argues that, in any development discussion, there are embedded ideological assumptions and value propositions; it is thus questionable to argue that ICT4D debates do not make reference to development studies. I argue that ideological underpinnings of development within ICT4D studies are 
not made manifest, however, they are implied, as indicated by the report that was analysed. Evidence from the analysis supported the fact that the role of ICT in development though has a strong basis within the market dominated and technocentric school, it has intensely shifted to encompass recent development paradigms of human dignity, capabilities, empowerment and socio-economic development. Although it furthers the idea of economic growth through free market, free trade, and globalisation targeting growth and prosperity these are viewed as only making sense if they enable human dignity and freedom.

The report acknowledges the ambiguity of the role of ICTs in development, however with a bias on the positive impacts of ICTs, which most studies fall victim to. Within this messy and tumultuous field, WDR16 should be applauded, as it took into consideration the recent developments in the field and use of many derivative frameworks: for example, the capability approach, millennium development goals for example by Clarke et al. (2013) and Kleine's Choice Framework. These frameworks are now increasingly adopted by researchers and international agencies (Mbarika, et al. 2005). These frameworks have been essential analysing the role of technology to different contexts.

\section{References}

Acılar, A.: Exploring the aspects of digital divide in a developing country. Issues in Informing Science and Information Technology 8, 231-244 (2011).

Avgerou, C.: Theoretical framing of ICT4D research. In International Conference on Social Implications of Computers in Developing Countries (pp. 10-23). Springer, Cham (2017, May).

Avgerou, C.: Discourses on ICT and development. Information Technologies \& International Development 6(3), 1-18 (2010).

Bankole, FO., Osei-Bryson, KM., Brown, I.: The impact of information and communications technology infrastructure and complementary factors on Intra-African Trade. Information Technology for Development 21(1), 12-28 (2015).

Brittan, L.: Globalisation vs. Sovereignty? The European Response: The 1997 Red Lecture and Related Speeches and Articles. Cambridge University Press, Cambridge (1998).

Castells, M.: Information technology, globalization and social development. UNRISD discussion paper no. 114. United Nations Research Institute for Social Development, Geneva (1999).

Clarke, S., Wylie, G., Zomer, H.: ICT 4 the MDGs? A perspective on ICTs' role in addressing urban poverty in the context of the Millennium Development Goals. Information Technologies \& International Development 9(4) 55 (2013).

Cukier, W., Middleton, C., Bauer, R.: The discourse of learning technology in Canada: understanding communication distortions and their implications for decision making. In Global and organizational discourse about information technology (197-221) (2003). 
Currie-Alder, B.: The state of development studies: origins, evolution and prospects. Canadian Journal of Development Studies/Revue canadienne d'études du development 37(1) 5-26 (2016).

Fairclough, N.: Analysing Discourse. Textual analysis for social research. London and New York: Routledge (2003).

Harindranath, G., Sein, M, K.: Revisiting the role of ICT in development. In proceedings of the 9th international conference on social implications of computers in developing countries, Portland International Conference, 924-937, Brazil, (2007).

Heeks, R.: Information and communication technologies, poverty and development. Institute for Development Policy and Management, Manchester (1999).

Heeks, R.: Do information and communication technologies (ICTs) contribute to development? Journal of International Development 22(5) 625-640 (2010).

Hwang, J.: Deconstructing the discourse of the global digital divide in the age of neo-liberal global economy (Doctoral Dissertation). The Pennsylvania State University, Pennsylvania (2006)

Kondowe, C.: Rethinking Technology Enabled Development: A Critique of the Neo-Liberal Perspective Embedded in ICT4D Studies. 10th International Development Informatics Association Conference (IDIA 2018). Johannesburg. 23-24 August 2018.

Kurz, H, D.: Marx on Technological Change: The Ricardian Heritage. Paper presented at the conference on 'Marxian Economics:A Centenary Appraisal. International Conference on Karl Marx’s Third Volume of Capital: 1894-1994', University of Bergamo, 15-17 December, (1994).

Levendis, J., Lee, S, H.: On the endogeneity of telecommunications and economic growth: evidence from Asia. Information Technology for Development 19(1) 62-85 (2013).

May, J., Dutton, V., Munyakazi, L.: Information and communication technologies as a pathway from poverty: evidence from East Africa. In Odera et al. (eds) ICT pathways to poverty reduction: Empirical evidence from East and Southern Africa. IDRC. Canada (2014).

Miroro, O, O., Adera, E, O., Political economy of ICTs and their effect on poverty. In Odera et al. (eds) ICT pathways to poverty reduction: Empirical evidence from East and Southern Africa. IDRC. Canada (2014).

Mishra, R.: Society and social policy: theories and practice of welfare. MacMillan, London (1981).

Ohmae K The borderless world power and strategy in the interlinked economy. Harper Business, New York (1991).

Pieterse, J, N.: Development theory. Sage London (2010).

Ranis, G.: Human development and economic growth. Center discussion paper no. 887. CT: Economic Growth Center, Yale University, New Haven (2004).

Rapley, J.: Understanding development. Lynne Rienner Publishers, London (2007).

Sahay, S.: Special issue on "IT and health care in developing countries". The Electronic Journal of Information Systems in Developing Countries 5(1)1-6 (2001). 
Sein, M. K., Thapa, D., Hatakka, M., \& Sæbø, Ø. A holistic perspective on the theoretical foundations for ICT4D research. Information Technology for Development, 1-19 (2018).

Sen, A.: The possibility of social choice. The American Economic Review, 89(3) 349-378 (1999).

Thompson, M.: Discourse, 'development' \& the 'digital divide’: ICT \& the World Bank. Review of African Political Economy 31(99) 103-123 (2004).

Veseth, M.: Selling globalization: the myth of the global economy. London: Lynne Rienner, (1998).

Wade, R, H.: Bridging the digital divide: new route to development or new form of dependency? Global Governance 8(4) 443-466 (2002).

World Bank.: Building institutions for markets. World Bank Washington DC (2016).

World Bank.: Digital dividends: World Bank, Washington DC (2016).

Ziai, A.: Development Discourse and Global History. From Colonialism to the Sustainable Development Goals. London: Routledge (2015). 